\title{
Atlantic forest soil as reference in the soil quality evaluation of coconut orchards (Cocos nucífera $\mathrm{L}$ ) under different management
}

\section{Solo de Mata Atlântica como referência na avaliação da qualidade do solo em pomares de coqueiro sob diferentes manejos}

\author{
Maria Isidoria Silva Gonzaga ${ }^{1 *}$; Marcus Vinicius Cunha Bispo ${ }^{2}$; \\ Thiago Lima da Silva ${ }^{3}$; Wallace Mello dos Santos²; Isaac Leal de Santana ${ }^{4}$
}

\begin{abstract}
The evaluation of the soil quality is important to identify potential problems of soil degradation. The assessment of the soil quality requires the determination of several soil parameters and the integration of specific soil properties measurements into mathematical models, such as the soil quality index (SQI). The aims of this study were to: (i) determine the SQI for an Ultisol under a remnant of Atlantic rain forest; (ii) use the SQI for the Atlantic rain forest as a reference to evaluate the effects of conventional and integrated management in coconut orchards. It was hypothesized that the conventional management of coconut (Cocos nucifera L.) orchards reduces the SQI compared with Atlantic rain forest. A soil quality index was constructed using an additive model that considered three main soil functions (the ability of the soil to promote root growth, water storage and flux, and nutrient supply) and a set of soil indicators. The SQI values were $0.66,0.54$ and 0.46 for the Atlantic forest, integrated and conventional orchards, respectively; therefore, there was decline in soil quality in both orchards. Even though there was an increase in the organic matter content in the integrated coconut orchard as result of the maintenance of the organic residues on the soil surface and the presence of cover crops, the SQI indicated that, in that type of highly weathered soil, a more conservative approach needs to be applied to avoid further soil quality degradation.
\end{abstract}

Key words: Soil attributes. Soil Quality. Agricultural sustainability. Native forest.

\section{Resumo}

A avaliação da qualidade do solo é importante para identificar potenciais problemas de degradação do solo. Para tanto, é necessário a determinação de vários parâmetros bem como a integração de propriedades específicas do solo em modelos matemáticos, como por exemplo, o índice de qualidade do solo (IQS). Os objetivos do presente estudo foram: i) determinar o IQS de um Argissolo sob Mata Atlântica; ii) utilizar o IQS da Mata Atlântica para avaliar os efeitos dos manejos convencional e integrado em pomares de coco (Cocos nucífera L). A hipótese postulada foi a de que o manejo convencional do coqueiro reduz o IQS quando comparado com a Mata Atlântica. O IQS foi construído usando um modelo aditivo que considerou três principais funções do solo (capacidade do solo em promover crescimento do sistema radicular, permitir o fluxo e o armazenamento de água, e fornecer nutrientes) e um grupo de indicadores. Os valores do IQS foram 0,66; 0,54; 0,46, para a Mata Atlântica, manejo integrado e manejo convencional, respectivamente. Portanto, houve um declínio na qualidade do solo nos dois

\footnotetext{
${ }^{1}$ Prof $^{a}$ Dr $^{\mathrm{a}}$, Departamento de Engenharia Agronômica, Universidade Federal de Sergipe, UFS, São Cristóvão, SE, Brasil. E-mail: mariaisisilva@gmail.com

${ }^{2}$ Eng $^{\text {os }}$ Agr ${ }^{\text {os }}$, UFS, São Cristóvão, SE, Brasil. E-mail: marcus@ufs.br; wallacemds@hotmail.com

${ }^{3}$ Prof. M.e, Instituto Federal de Sergipe, IFS, Nossa Senhora da Gloria, SE, Brasil. E-mail: thiagolim@hotmail.com

${ }^{4}$ Eng $^{\circ}$ Florestal, UFS, São Cristóvão, SE, Brasil. E-mail: isaac.brother@hotmail.com

* Author for correspondence
} 
pomares. Embora tenha sido observado um aumento no teor de material orgânico no pomar de manejo integrado, onde os resíduos orgânicos e culturas de cobertura são dispostos na superfície do solo, o IQS indicou que, em solos muito intemperizados, as práticas conservacionistas precisam ser mais efetivas.

Palavras-chave: Atributos do solo. Qualidade do solo. Sustentabilidade ambiental. Floresta nativa.

\section{Introduction}

Conventional agricultural systems still predominate for the production of perennial tropical fruits in many countries, including Brazil. In these systems, the soil in the inter-rows is frequently bare, which can lead to erosion and to reductions in the soil quality and health (CINTRA et al., 2008; FIALHO et al., 2013). In addition to the negative impacts caused by conventional soil management on soil quality, the natural physical and chemical characteristics of most tropical soils limit their potential for crop production. Some of these soils are highly weathered and have cohesive layers that affect the dynamics of the movement of water and nutrients through the soil profile, causing reductions in crop productivity and sustainability, and increasing the risk of erosion (FERNANDES et al., 2011; MARTINS et al., 2011).

Under natural vegetation, these soils are protected from degradation due to erosive rainfall. After clearing and cultivation of natural forests, excessive loss of soil carbon, nutrients and reduction in biological activity can occur. Therefore, appropriate management practices are needed in order to reduce the decline in soil quality (OGUNWOLE et al., 2014), such as the application of soil amendments, mechanization, and irrigation. In fact, the combination of certain conventional systems with conservation practices, such as permanent grassland, cover crops, mulching and manuring with green legumes, farmyard manure and compost, may offer a way of mitigating problems of soil degradation (AZIZ et al., 2013).

The decline in soil quality needs to be monitored. Although there are well established soil parameters that can be related to the changes due to soil use and management, an acceptable and cost effective standardized method to assess soil quality is still missing, especially an approach that can explain the complex relationships between soil property measurements and overall soil quality. According to Larson and Pierce (1994), soil quality cannot be measured directly, but soil properties that are sensitive to changes in management can be used as indicators that reflect the different soil functions (FERNANDES et al., 2011; MUKHERJEE; LAL, 2014). The soil indicators are then grouped into a minimum data set and integrated in mathematical models for calculating a SQI.

Karlen and Stott (1994) suggested an additive model in which the main soil functions and their respective indicators are first identified. Weights are then assigned that define the importance of the indicator for each of the functions selected as components of a SQI. Some attempts have been made to determine the soil quality index using the Karlen and Stott's model (MELO FILHO et al., 2007; MARZAIOLI et al., 2010), and interesting results have been observed. In most of the Brazilian northeast region, the remaining Atlantic Forest occurs on flat table lands soils as small fragments isolated from each other by agriculture or nonforest systems (MORELLATO; HADDAD, 2000). The almost complete extinction of this biome makes difficult to find sites to undertake this kind of investigation on soil quality. In fact, the absence of proper baselines is a common problem in many countries.

Furthermore, no evaluation on soil quality has been done so far in coconut (Cocos nucifera L) orchards, which occupy large agricultural areas in tropical countries. According to the UN's Food and Agriculture Organization (FAO), Brazil has a coconut production area of more than 250000 ha and produces almost three million tons of coconuts per year, being the world's fourth largest producer. 
Therefore, the hypothesis adopted in the present work was that the management employed in the coconut orchards impacted the soil quality index as compared with the native forest. The aims were therefore to: (i) determine the SQI value of an Ultisol under a remnant of Atlantic rain forest; and (ii) use the SQI value of the undisturbed area as a reference to evaluate the effects of conventional and integrated management practices in two coconut production systems in northeast Brazil.

\section{Materials and Methods}

\section{Site characterization and experimental design}

The fieldwork was conducted in a coconut irrigated farm in the State of Sergipe $\left(10^{\circ} 19^{\prime}\right.$ $\left.12^{\prime \prime} \mathrm{S}, 36^{\circ} 34^{\prime} 46^{\prime \prime} \mathrm{W}\right)$, in northeastern Brazil. The climate of the region is BSh type, according to the Köppen-Geiger classification (PEEL et al., 2007), with dry summers and rainfall concentrated in the months of may to september. The mean annual precipitation and temperature are $1200 \mathrm{~mm}$ and 30 ${ }^{\circ} \mathrm{C}$, respectively. The soils at the sites were classified as DystrophicYellow Ultisol (EMBRAPA, 2006).

The experimental design consisted of three treatments located in experimental farms, where types of land use (Atlantic forest, conventional coconut orchard and integrated coconut orchard) were assigned as whole plots and the sampling depth (0-10 $\mathrm{cm}$ and $10-20 \mathrm{~cm})$ as subplots. Soil textural characteristics were 76,4 to $85,6 \%$ Sand; 10,2 to $15,8 \%$ Silt; and 4,22 to 7,78\% Clay, in the $0-10 \mathrm{~cm}$ layer, and 67,6 to $84,4 \%$ Sand; 10,1 to $23,1 \%$ Silt; and 5,53 to $9,04 \%$ Clay, in the $10-20 \mathrm{~cm}$ layer.

\section{Description of the treatments}

The undisturbed area is a remnant of the Atlantic Rainforest located adjacent to the orchards. The vegetation is typical tropical humid forest, with perennial trees varying from 15 to $30 \mathrm{~m}$ in height, where $53 \%$ are of the Myrtaceae Family, followed by the Fabaceae, Anacardiaceae and Sapindaceae Families (SILVA; ELLI, 2000).

Both orchards were first planted in 1998, in approximately 50 ha (25 ha each area), in flat table land, with $7.5 \mathrm{~m} \times 7.5 \mathrm{~m} \times 7.5$ spacing and 205 plants per hectare. Irrigation was performed daily $(150 \mathrm{~L}$ day $^{-1}$ plant $^{-1}$ ) through the mini-sprinkler system. Fertilizer was applied annually using $1200 \mathrm{~g} \mathrm{~N}$ plant $^{-1}$, $400 \mathrm{~g} \mathrm{~K}_{2} \mathrm{O}$ plant ${ }^{-1}$ and $1200 \mathrm{~g} \mathrm{P}_{2} \mathrm{O}_{5}$ plant $^{-1}$. The difference between the two orchards is in the tillage practices. The conventional coconut orchard was managed only by mechanical and chemical weed control in the inter rows when it was needed. The integrated coconut orchard was managed using conservation practices that include organic fertilization (castor bean cake and cow manure), leguminous cover crops (Pueraria Phaseoloides (Roxb.) Benth, grass (Brachiaria decumbens Stapf), and mulching with the coconut crop residues in the inter rows.

Indicator selection and elaboration of the soil quality index (SQI)

The research approach used in this study can be summarized as follow:

a) The capacity of the soil to sustain plant growth and productivity was set as the management goal;

b) Three soil functions were selected to meet this goal: ability to sustain root growth (RG), ability to facilitate water storage and flow (WSF), and ability to supply nutrients (NS).To each function was assigned a weight.

c) For each soil function, a group of quality indicator parameters was identified and selected to form a minimum data set. A weight was assigned to each soil indicator.

d) The measured values of the soil indicators were transformed into unitless scores from 0 to 1 using conversion algorithms (standard scoring functions); 
e) Finally, the SQI was calculated by integrating the scores and the respective weights of functions and indicator.

The selection of soil quality indicators to be included in the SQI (Table 1) was based on the Karlen and Stott's (1994) additive model, due to its flexibility and ease of use. Moreover, this index has been used by other research groups in Brazil (MELO FILHO et al., 2007; FERNANDES et al., 2011). Critical limits or threshold values for the indicators were taken from Melo Filho et al. (2007), since the soil and climate were similar. The scores for each soil indicator were determined according to Glover et al. (2000), with numerical weights calculated using standardized scoring functions. The standardization of indicators using scores that vary from 0.0 to 1.0 enables the integration of indicators determined using different units of measurement.

The soil functions were weighted and integrated according to the following expression:

$$
\begin{gathered}
\text { Soil quality index }(\mathrm{SQI})= \\
\left(\left(\mathrm{RG}\left(\mathrm{Wf}_{1}\right)+\mathrm{WSF}\left(\mathrm{Wf}_{2}\right)+\mathrm{NS}\left(\mathrm{Wf}_{3}\right)\right)\right.
\end{gathered}
$$

Numerical weightings $\left(\mathrm{W}_{\mathrm{i}}\right)$ were assigned to each function (f)(Table 1) according to its importance in contributing to the overall goal of maintaining soil quality (under the conditions of this study). The calculation of the SQI was as follows:

$$
\sum \mathrm{Wfi}=\mathrm{I}_{1} \mathrm{xwI}_{1}+\ldots+\mathrm{I}_{\mathrm{n}} \mathrm{xwI}_{\mathrm{n}}
$$

In this expression, Wfi is the partial contribution of each individual main function (Table 1) to the global value of the SQI, $I_{n}$ is the value of a given indicator for the main function being evaluated, and $\mathrm{wI}_{\mathrm{n}}$ is a relative weighting value for each indicator (Table 1), determined according to the degree of importance of the indicator in the index. Quantification of the numerical weightings involved consideration of the type of agricultural land use and the requirements of the crop.

The sum of the weights of the major soil functions cannot exceed a value of 1.0 (KARLEN; STOTT, 1994), since this SQI value indicates an ideal soil (according to the intended purpose). Karlen and Stott (1994) also suggested a value of 0.5 as the threshold between good and poor soil quality. A value of zero indicates a condition of extreme soil degradation, where the soil is no longer able to perform its functions.

Glover et al. (2000) employed an approach developed by Wymore (1993) for engineering systems, and created scoring curves ("more is better", "less is better", and "optimum value") of standardized scores that corresponded to the real values of the indicators. Cation exchange capacity, available water, organic matter concentration, sum of bases, and phosphorus concentration were scored using a "more is better" curve. Bulk density, resistance to penetration, and $\mathrm{Al}$ saturation were scored using a "less is better" curve. Soil pH, macroporosity, and total porosity were scored using an "optimum value" curve. 


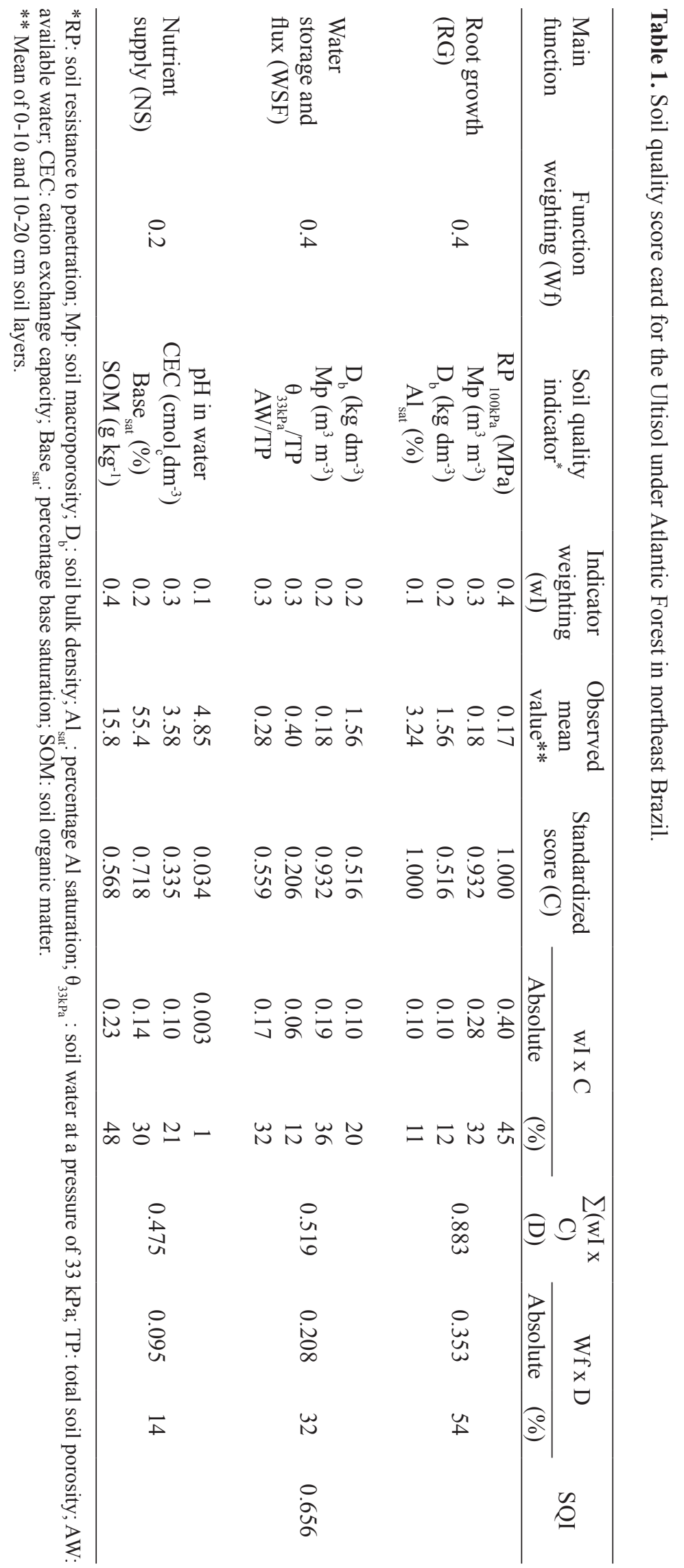


The scoring curves were generated from the following equation:

$$
\begin{gathered}
\text { Normalized score }(v)= \\
1 /\left[1+((B-L) /(x-L))^{2 S(B+x-2 L)}\right]
\end{gathered}
$$

Here, B is the baseline value of the soil property (where the score is 0.5 ), $\mathrm{L}$ is the lower threshold, $\mathrm{S}$ is the slope of the tangent to the curve at the baseline, and $\mathrm{x}$ is the soil property value. Standard scoring functions used for the normalization of soil quality indicators can be found in Andrews and Carroll (2001) and in Fernandes et al. (2011).

\section{Soil sampling and analysis}

Each experimental area was composed of three subplots of approximately1 ha. From each subplot and each depth, 15 samples were collected randomly midway between trees within the tree rows, using a soil auger and subsequently mixed to form a composite soil sample. Additionally, seven intact core samples $(0.05 \mathrm{~m}$ diameter and $0.02 \mathrm{~m}$ height) were collected randomly from each depth, from each of the three subplots of each evaluated area.

The composite soil samples were transported to the laboratory in plastic bags, air dried, sieved through a $2 \mathrm{~mm}$ screen, and stored. Soil texture was analyzed as described by Gee and Bauder (1986). Sand, silt and clay content were 807,128 and $65 \mathrm{~g}$ $\mathrm{kg}^{-1}$, respectively, in the $0-10 \mathrm{~cm}$ depth, and 756 , 166 and $78 \mathrm{~g} \mathrm{~kg}^{-1}$, respectively, in the $10-20 \mathrm{~cm}$ depth. Soil $\mathrm{pH}$ was determined using a soil to water ratio of $1: 2.5$. Base saturation percentage (Base ${ }_{\text {sat }}$ ), cation exchange capacity (CEC), and aluminum saturation percentage $(\mathrm{Al}$ sat $)$ were determined as described by Embrapa (2009). Soil organic matter was determined by the Walkley Black method (NELSON; SOMMERS, 1982).

The intact core samples were used to determine soil porosity, macroporosity, and bulk density, according to Embrapa (2009). Soil water content was determined according to Klute (1986), using matric potentials of -33 and $-1500 \mathrm{KPa}$.

\section{Statistical analysis}

The results were submitted to analysis of variance (ANOVA) for identification of relevant effects, and the means were compared using the Tukey test $(P<0.05)$. All the analyses were performed with SISVAR v. 5.0 software (FERREIRA, 2003).

\section{Results and Discussion}

Soil quality index evaluation of the forest soil

The calculated SQI value for the Atlantic Forest soil is shown in Table 1 . The value of 0.66 obtained for the $0-20 \mathrm{~cm}$ depth indicated that the forest soil was of moderate quality, according to the SQI scale (ranging from 0 to 1) (MELO FILHO et al., 2007). The contributions of the main soil functions to the SQI were root growth $>$ water storage and flow $>$ nutrient supply.

The Yellow Ultisol evaluated in this study showed severe physical and chemical restrictions to plant growth, due to high acidity, low chemical fertility, and the presence of a natural cohesive layer (usually below a depth of $20 \mathrm{~cm}$ ). Although the soil presented some potential $(\mathrm{SQI}=0.66)$, the agricultural use would demand management such as protection of the soil surface with organic residues and cover crops, reduced or no-tillage, liming and fertilization, and a more efficient irrigation. These strategies could help to reduce soil degradation, especially where the soil is highly susceptible to erosion and compaction (OGUNWOLE et al., 2014), as in the present case.

Determination of the SQI for each individual soil depth confirmed the natural limitations of the forest soil (Table 2). Soil depth was associated with sharp reductions in the values obtained for the three soil functions (especially water storage and flux, 
and nutrient supply), due to reduced organic matter content and macroporosity, along with increases in bulk density, resistance to penetration, Al saturation, and acidity (Tables 3 and 4$)$. The surface soil (0-10 $\mathrm{cm}$ ) had an SQI value of 0.78 whereas the SQI value for the 10-20 cm depth was 0.53 .

Table 2. Soil quality index (SQI) and percentage contribution of each soil function to the SQI assessment on the integrated orchard, conventional orchard, and Atlantic forest, in northeast Brazil.

\begin{tabular}{|c|c|c|c|c|}
\hline \multirow{2}{*}{ Soil main function } & \multirow{2}{*}{$\begin{array}{c}\text { Soil depth } \\
\mathrm{cm}\end{array}$} & \multicolumn{3}{|c|}{ Land use / management } \\
\hline & & Integrated orchard & Conventional orchard & Atlantic Forest \\
\hline \multirow{3}{*}{ Root growth } & $0-10$ & $0.33 * \mathrm{Ba}$ & $0.27 \mathrm{Ca}$ & $0.40 \mathrm{Aa}$ \\
\hline & $10-20$ & $0.20 \mathrm{Bb}$ & $0.19 \mathrm{Bb}$ & $0.31 \mathrm{Ab}$ \\
\hline & Mean & $0.27(50 \%) \mathrm{B}$ & $0.23(50 \%) \mathrm{C}$ & $0.35(54 \%) \mathrm{A}$ \\
\hline \multirow{3}{*}{ Water storage and flux } & $0-10$ & $0.19 \mathrm{Ba}$ & $0.15 \mathrm{Ca}$ & $0.25 \mathrm{Aa}$ \\
\hline & $10-20$ & $0.11 \mathrm{Bb}$ & $0.16 \mathrm{Aa}$ & $0.17 \mathrm{Ab}$ \\
\hline & Mean & $0.15(28 \%) \mathrm{B}$ & $0.16(35 \%) \mathrm{B}$ & $0.21(32 \%) \mathrm{A}$ \\
\hline \multirow{3}{*}{ Nutrient supply } & $0-10$ & $0.15 \mathrm{Aa}$ & $0.09 \mathrm{Ca}$ & $0.13 \mathrm{Ba}$ \\
\hline & $10-20$ & $0.09 \mathrm{Ab}$ & $0.05 \mathrm{Bb}$ & $0.06 \mathrm{Bb}$ \\
\hline & Mean & $0.12(22 \%) \mathrm{A}$ & $0.07(15 \%) B$ & $0.09(14 \%) \mathrm{B}$ \\
\hline \multirow{3}{*}{ SQI } & $0-10$ & $0.67 \mathrm{Ba}$ & $0.51 \mathrm{Ca}$ & $0.78 \mathrm{Aa}$ \\
\hline & $10-20$ & $0.40 \mathrm{Bb}$ & $0.40 \mathrm{Bb}$ & $0.53 \mathrm{Ab}$ \\
\hline & Mean & $0.54 \mathrm{~B}$ & $0.46 \mathrm{C}$ & $0.66 \mathrm{~A}$ \\
\hline
\end{tabular}

*Mean values followed by the same lower case letters in a column, and by the same upper case letters in a row, are not significantly different according to Tukey's test $(\mathrm{p}<0.05)$.

Melo Filho et al. (2007), using the same soil functions and indicators employed in the present study, applied the Karlen and Stott (1994) model to an Oxisol under Atlantic Forest, and obtained an SQI value of 0.46 , which is considered low for agricultural production. The authors attributed their results to the very acidic nature of the soil, low fertility and compaction.

Soil quality indices for the conventional and integrated coconut orchards

Ashift from natural vegetation to agricultural land is normally associated with a decrease in soil quality (LAL, 2012), and here the overall SQI values for both orchard soils (means of values for the two soil depths) were lower than for the Atlantic Forest soil (Table 2). The soil quality of the integrated coconut orchard $(\mathrm{SQI}=0.54)$ was above the threshold value
(0.50), whereas that of the conventional coconut orchard was below this threshold (SQI $=0.46$ ). These data showed inappropriate management, especially because the surface soil was sandy (75-85\% sand content) and was therefore highly susceptible to erosion when tilled (CINTRA et al., 2008). Excessive and frequent irrigation, along with tillage and the passage of vehicles on wet soil, could be the most important causes of soil degradation in this region.

The management employed in the integrated orchard resulted in a better SQI value, compared with the conventional orchard (Table 2). Some of the indicators were significantly higher for the integrated orchard, which received continuous inputs of crop residues, compared with the conventional orchard (Tables 3 and 4). This reinforces the recommendation for the use of conservation practices in coconut orchards (CHABI-OLAYE et al., 2005). 
Table 3. Selected soil physical quality indicators used to compose the Soil Quality Index on the integrated orchard, conventional orchard, and Atlantic forest, in northeast Brazil.

\begin{tabular}{lcccc}
\hline Soil chemical & Depth & \multicolumn{3}{c}{ Land use / management } \\
\cline { 2 - 5 } Indicator & $\mathrm{cm}$ & Integrated orchard & Conventional orchard & Atlantic Forest \\
\hline $\mathrm{RP} 100 \mathrm{kPa}$ & $0-10$ & $0.80 \mathrm{Ab}$ & $0.66 \mathrm{Bb}$ & $0.12 \mathrm{Cb}$ \\
$(\mathrm{MPa})$ & $10-20$ & $1.02 \mathrm{Ba}$ & $1.24 \mathrm{Aa}$ & $0.22 \mathrm{Ca}$ \\
\hline $\mathrm{Mp}$ & $0-10$ & $0.17 \mathrm{Aba}$ & $0.15 \mathrm{Ba}$ & $0.20 \mathrm{Aa}$ \\
$\left(\mathrm{m}^{3} \mathrm{~m}^{-3}\right)$ & $10-20$ & $0.14 \mathrm{Aa}$ & $0.16 \mathrm{Aa}$ & $0.16 \mathrm{Ab}$ \\
\hline $\mathrm{D}_{\mathrm{b}}$ & $0-10$ & $1.55 \mathrm{Bb}$ & $1.62 \mathrm{Aa}$ & $1.51 \mathrm{Cb}$ \\
$\left(\mathrm{kg} \mathrm{dm}^{-3}\right)$ & $10-20$ & $1.62 \mathrm{Aa}$ & $1.62 \mathrm{Aa}$ & $1.62 \mathrm{Aa}$ \\
\hline \multirow{2}{*}{$\theta_{33 \mathrm{kPa}} / \mathrm{TP}$} & $0-10$ & $0.33 \mathrm{Bb}$ & $0.39 \mathrm{Aa}$ & $0.40 \mathrm{Aa}$ \\
\multirow{2}{*}{$\mathrm{AW} / \mathrm{TP}$} & $10-20$ & $0.39 \mathrm{Aa}$ & $0.40 \mathrm{Aa}$ & $0.40 \mathrm{Aa}$ \\
& $0-10$ & $0.25 \mathrm{Aa}$ & $0.30 \mathrm{Aa}$ & $0.30 \mathrm{Aa}$ \\
& $10-20$ & $0.21 \mathrm{Aa}$ & $0.30 \mathrm{Aa}$ & $0.26 \mathrm{Aa}$ \\
\hline
\end{tabular}

RP: soil resistance to penetration; Mp: soil macroporosity; $\mathrm{D}_{\mathrm{b}}$ : soil bulk density; $\theta_{33 \mathrm{kPa}}$ : soil water content at a pressure of $33 \mathrm{kPa}$; TP: total soil porosity; AW: available water.

* Mean values followed by the same lower case letters in a column, and by the same upper case letters in a row, are not significantly different according to Tukey's test $(\mathrm{p}<0.05)$.

There were reductions in soil quality with depth in all the evaluated areas (Table 2), and this trend was also observed for all the individual soil functions that constituted the SQI. In the Integrated orchard, soil quality reduction with depth was indicated by both physical and chemical parameters. Increased soil density and resistance to penetration (MRP) were observed along with a reduction in soil macroporosity (Table 3). At the same time, there were significant reductions in SOM and CEC with soil depth (Table 4). For the conventional orchard, the reduction in soil quality with depth was mostly related to lower values of the chemical indicators (pH, CEC, V, and SOM) (Table 4), and there was a significant increase in the $\mathrm{Al}$ saturation percentage.

For the root growth (RG) main function (Table 2), SQI was greater for the natural forest compared with conventional or integrated orchards. This function contributed the most to the SQI, with a weighting value of 0.4 (Table 1), which could be explained by a low mechanical resistance to penetration (which had a high score (1) and accounted for $45 \%$ of the RG function contribution), as well as the macroporosity of the soil. Soil resistance to penetration (RP) varied from $0.12 \mathrm{MPa}$ (for the soil under natural vegetation) to $1.24 \mathrm{MPa}$ (for the conventional coconut orchard) (Table 3). These values were below 2.0 $\mathrm{MPa}$, which is the limiting value at which root growth can become restricted (BENGOUGH et al., 2006).

Furthermore, macropores in the surface layer varied from 0.17 to $0.20 \mathrm{~m}^{3} \mathrm{~m}^{-3}$, ranked in the order: Atlantic Forest $>$ integrated orchard $>$ conventional orchard. A value of $0.10 \mathrm{~m}^{3} \mathrm{~m}^{-3}$ is considered to be a threshold value, below which root growth and soil aeration are severely restricted. Cintra et al. (2008) found a similar value for the macroporosity of the subsurface soil depth $\left(0.15 \mathrm{~m}^{3} \mathrm{~m}^{-3}\right)$ in the same location.

The water storage and flux (WSF) function of the soil contributed less than $40 \%$ to SQI (Table 2). This was probably related to the low capacity of this soil to store water, due to the high percentage of sand, low total porosity, and low organic matter content, which may have affected the soil structure. The change in land use affected the WSF function, since the values were ranked in the order: Atlantic Forest $>$ conventional orchard $>$ integrated orchard. 
Table 4. Selected soil chemical quality indicators used to compose the Soil Quality Index on the integrated orchard, conventional orchard, and Atlantic forest, in northeast Brazil.

\begin{tabular}{lcccc}
\hline \multirow{2}{*}{$\begin{array}{l}\text { Soil chemical } \\
\text { Indicator }\end{array}$} & Depth & \multicolumn{3}{c}{ Land use / management } \\
\cline { 2 - 5 } $\mathrm{pH}$ & $\mathrm{cm}$ & Integrated orchard & Conventional orchard & Atlantic Forest \\
\hline \multirow{2}{*}{$\mathrm{CEC}$} & $0-10$ & $6.27 \mathrm{Aa}^{*}$ & $6.66 \mathrm{Aa}$ & $5.05 \mathrm{Ba}$ \\
$\left(\mathrm{cmol}_{\mathrm{c}} \mathrm{kg}^{-1}\right)$ & $10-20$ & $6.50 \mathrm{Aa}$ & $5.48 \mathrm{Bb}$ & $4.66 \mathrm{Ca}$ \\
\hline $\mathrm{Base}_{\text {sat }}$ & $0-10$ & $6.98 \mathrm{Aa}$ & $4.13 \mathrm{Ba}$ & $4.61 \mathrm{Ba}$ \\
$(\%)$ & $10-20$ & $4.58 \mathrm{Ab}$ & $2.53 \mathrm{Bb}$ & $2.55 \mathrm{Bb}$ \\
\hline $\mathrm{SOM}$ & $0-10$ & $90.27 \mathrm{Aa}$ & $91.72 \mathrm{Aa}$ & $60.25 \mathrm{Ba}$ \\
$\left(\mathrm{g} \mathrm{kg}^{-1}\right)$ & $10-20$ & $87.36 \mathrm{Aa}$ & $83.04 \mathrm{Ab}$ & $50.65 \mathrm{Bb}$ \\
\hline $\mathrm{Al}_{\text {sat }}$ & $0-10$ & $17.7 \mathrm{Aa}$ & $10.9 \mathrm{Ba}$ & $21.1 \mathrm{Aa}$ \\
$(\%)$ & $10-20$ & $11.0 \mathrm{Ab}$ & $5.90 \mathrm{Bb}$ & $10.5 \mathrm{Ab}$ \\
\hline
\end{tabular}

CEC: cation exchange capacity; Base : percentage base saturation; SOM: soil organic matter; $\mathrm{Al}_{\text {san }}$ : percentage $\mathrm{Al}$ saturation. *Mean values followed by the same lower case letters in a column, and by the same upper case letters in a row, are not significantly different according to Tukey's test $(\mathrm{p}<0.05)$.

The nutrient supply capacity (NS) main function, which received a weighting value of 0.2 (Table 1), contributed 14 to $22 \%$ of the overall SQI, depending on the land use (Table 2). The NS values were ranked in the order: integrated orchard $>$ conventional orchard $>$ Atlantic Forest. This trend was the inverse of that obtained for the WSF function, and revealed a positive impact on soil quality due to improvements in the chemical characteristics of the cultivated soils (Table 4). For the soil under Atlantic Forest, the values obtained for soil $\mathrm{pH}$, organic matter content, $\mathrm{CEC}$, and Al saturation were typical for an Ultisol under tropical climate. Liming and fertilization are therefore essential if such soils are to be cultivated. Routine soil analyses, supported by more objective soil quality assessments, would help provide better management of soil fertility.

The findings demonstrated that the use of a soil under natural vegetation as a reference can be very helpful for the assessment of soil quality in agricultural areas. It also showed that the soil quality assessment as used in this study might be a procedure that could be adopted elsewhere. In other studies (GLOVER et al., 2000; FERNANDES et al., 2011), soil quality indices have been established by comparing soils under different management systems. This is also a valid procedure when it is not possible to use an undisturbed soil as reference.

\section{Conclusion}

Considering that the Atlantic Forest is an undisturbed ecosystem, it was expected to have a high SQI. However, the SQI was of low to moderate quality due to the natural soil physical and chemical constraints, which have to be addressed before the change in land use, especially for agriculture. The use of the Atlantic Forest soil to cultivate coconut for more than 15 years, regardless of the management practices, reduced further the SQI, suggesting that more appropriate approaches need to be applied to avoid soil degradation. Therefore, under the conditions of the study, the SQI model was useful in showing the effects of the land use.

\section{Acknowledgements}

The authors are grateful to the Brazilian National Scientific and Technological Development Council (CNPq) for financial support of this work. We thank Mr. Raimundo Prata and Mr. Marcus Martins for technical assistance during sample analysis. 


\section{References}

ANDREWS, S. S.; CARROLL, C. R. Designing a decision tool for sustainable agroecosystem management: soil quality assessment of a poultry litter management case study. Ecological Applications, Washington, v. 11, n. 6, p. 1573-1585, 2014.

AZIZ, I.; MAHMOOD, T.; RAFIK ISLAM, K. Effect of long term no-till and conventional tillage practices on soil quality. Soil and Tillage Research, Amsterdam, v. 131, n. 1, p. 28-35, 2013.

BENGOUGH, A. G.; BRANSBY, M. F.; HANS, J.; MCKENNA, S. J.; ROBERTS, T. J.; VALENTINE, T. A. Root response to soil physical conditions: growth dynamics from field to cell. Journal of Experimental Botany, Oxford, v. 57, n. 2, p. 437-447, 2006.

CHABI-OLAYE, A.; NOLTE, C.; SCHULTHESS, F.; BORGEMEISTER, C. Effects of grain legumes and cover crops on maize yield and plant damage by Busseola fusca (Fuller) (Lepidoptera: Noctuidae) in the humid forest of southern Cameroon. Agriculture, Ecosystems and Environment, Amsterdam, v. 108, n. 1, p. 17-28, 2005.

CINTRA, F. L. D.; RESENDE, R. S.; LEAL, M. L. S. Distribuição de raízes de coqueiro anão sob volumes de água em solo coeso dos tabuleiros. Revista Brasileira de Engenharia Agrícola e Ambiental, Campina Grande, v. 12, n. 6, p. 614-619, 2008.

EMPRESA BRASILEIRA DE PESQUISA AGROPECUÁRIA - EMBRAPA. Embrapa solos. Manual de análises químicas de solos, plantas e fertilizantes. Brasília: Embrapa Informação Tecnológica; Embrapa Solos, 2009. 627 p.

Centro Nacional de Pesquisa de Solos. Sistema brasileiro de classificação de solos. 2. ed. rev. atual. Rio de Janeiro: Embrapa Solos, 2006. 306 p.

FERNANDES, J. C.; GAMERO, C. A.; RODRIGUES, J. G. L.; MIRÁS-AVALOS, J. M. Determination of the soil quality index of a Paleudult under sunflower culture and different management systems. Soil and Tillage Research, Amsterdam, v. 112, n. 2, p. 167-174, 2011.

FERREIRA, D. F. Sisvar version 4.2. Lavras: Universidade Federal de Lavras, 2003. 79 p.

FIALHO, J. S.; AGUIAR, M. I.; MAIA, L. S.; MAGALHAES, R. B.; ARAUJO, F. C. S.; CAMPANHA, M. M.; OLIVEIRA, T. S. Soil quality, resistance and resilience in traditional agricultural and agroforestry ecosystems in Brazilian semiarid region. African Journal of Agricultural Research, Mauritius, v. 8, n. 40, p. 50205031, 2013.
GEE, G. W.; BAUDER, J. W. Particle-size analysis. In: KLUTE, A. (Ed.). Methods of soil analysis, part 1, physical and mineral methods. Madison: American Society of Agronomy, Soil Science Society of America, 1986. p. 383-401. (Agronomy series, 9).

GLOVER, J. D.; REGANOLD, J. P.; ANDREWS, P. K. Systematic method for rating soil quality of conventional, organic, and integrated apple orchards in Washington State. Agriculture, Ecosystems and Environment, Amsterdam, v. 80, n. 1, p. 29-45, 2000.

KARLEN, D. L.; STOTT, D. E. A. framework for evaluating physical and chemical indicators of soil quality. In: DORAN, J. W.; COLEMAN, D. C.; BEZDICEK, D. F.; STEWART, B. A. (Ed.). Defining soil quality for a sustainable environment. Madison: Soil Science Society of America/American Society of Agronomy, 1994. p. 5371.

KLUTE, A. Water retention: laboratory methods. In: BLACK, C. A. (Ed.). Methods of soil analysis. I. Physical and mineralogical methods. Madison: American Society of Agronomy, Soil Science Society of America, 1986. p. 635-662.

LAL, R. Climate change and soil degradation mitigation by sustainable management of soils and other natural resources. Agricultural Research, v. 1, n. 3, p. 199-212, 2012.

LARSON, W. E.; PIERCE, F. J. The dynamics of soil quality as a measure of sustainable management. In: DORAN, J. W.; COLEMAN, D. C.; BEZDIECK, D. F.; STEWART, B. A. (Ed.). Defining soil quality for a sustainable environment. Madison: Soil Science Society of America, Soil Science Society of America, 1994. n. 35, Chapter 3, p. 37-52.

MARTINS, S. G.; AVANZI, J. C.; SILVA, M. L. N.; CURI, N.; FONSECA, S. Soil erodibility in the Brazilian coastal plains. Pesquisa Agropecuaria Tropical, Goiânia, v. 41, n. 3, p. 322-327, 2011.

MARZAIOLI, R.; DÁSCOLI, R. D.; PASCALE, R. A.; RUTIGLIANO, F. A. Soil quality in a Mediterranean area of Southern Italy as related to different land use types. Applied Soil Ecology, Amsterdam, v. 44, n. 3, p. 205-212, 2010.

MELO FILHO, J. F.; VASCONCELOS, J. L.; SOUZA, L. S. Determination of the subsurface quality index in a Cohesive Oxisol under natural forest in Coastal Plains. Brazilian Journal of Soil Science, Viçosa, v. 31, n. 6, p. 1599-1608, 2007.

MORELLATO, I. P. C.; HADDAD, C. F. B. Introduction: the Brazilian Atlantic Forest. Biotropica, Washington, v. 32, n. 4, p. 786-792, 2000. 
MUKHERJEE, A.; LAL, R. Comparison of soil quality index using three methods. PLoS ONE, San Francisco, v. 9, n. 8, p. 1-15, aug. 2014.

NELSON, D. W.; SOMMERS, L. E. Total carbon, organic carbon and organic matter. In: PAGE, A. L.; MILLER, R. H.; KEENEY, D. R. (Ed.). Methods of soil analysis: chemical and microbiological properties. part 2. Madison: Soil Science Society of America, 1982. p. 539-579.

OGUNWOLE, J.; SHARMA, B. R.; MCCARTNEY, M. P.; ZENADIN, B.; LETA, G. Land use impact on soil physical quality and soil structure in three highland watershed of Ethipoia. Advances in Plants and Agricultural Research, Edmond, v. 1, n. 4, p. 1-9, 2014.
PEEL, M. C.; FINLAYSON, B. L.; MCMAHON, T. A. Updated world map of the Koppen-Geiger climate classification. Hydrological Earth System Science, Hanover, v. 11, n. 5, p. 1633-1644, 2007.

SILVA, J. M. C.; ELLI, M. Tree species impoverishment and the future flora of the Atlantic forest of northeast Brazil. Nature, Baltimore, v. 404, n. 72, p. 72-74, 2000.

WYMORE, A. W. Model-based systems engineering: an introduction to the mathematical theory of discrete systems and to the tricotyledon theory of system design. Boca Raton: CRC Press, 1993. 710 p. 
